\title{
Case Report \\ More Common Than You Think: Common Variable Immune Deficiency
}

\author{
Abimbola Aderinto, ${ }^{1,2}$ Vibav Mouli, ${ }^{1,2}$ Danielle F. Resar, ${ }^{1,2}$ and Linda M. S. Resar ${ }^{1,2,3,4,5}$ \\ ${ }^{1}$ Department of Medicine, The Johns Hopkins University School of Medicine, Baltimore, MD 21205, USA \\ ${ }^{2}$ Hematology Division, The Johns Hopkins University School of Medicine, Baltimore, MD 21205, USA \\ ${ }^{3}$ Department of Oncology, The Johns Hopkins University School of Medicine, Baltimore, MD 21205, USA \\ ${ }^{4}$ The Institute for Cellular Engineering, The Johns Hopkins University School of Medicine, Baltimore, MD 21205, USA \\ ${ }^{5}$ The Johns Hopkins University School of Medicine, Ross Research Building, Room 1025, 720 Rutland Avenue, Baltimore, \\ MD 21205, USA
}

Correspondence should be addressed to Linda M. S. Resar; lresar@jhmi.edu

Received 19 July 2013; Accepted 30 September 2013

Academic Editors: M. C. Kyrtsonis and B. Longo-Mbenza

Copyright (C) 2013 Abimbola Aderinto et al. This is an open access article distributed under the Creative Commons Attribution License, which permits unrestricted use, distribution, and reproduction in any medium, provided the original work is properly cited.

We report a challenging case of a 16-year-old male who presented with thrombocytopenia and eluded a definitive diagnosis for over 2 years. He was initially diagnosed with a viral illness, although he later developed adenopathy and splenomegaly. An evaluation by an oncologist was unrevealing. He worked on a farm with livestock exposure and was later diagnosed with an atypical, zoonotic infection. Despite appropriate antibiotic therapy, the thrombocytopenia and splenomegaly persisted. Further evaluation revealed that he has a relatively common immunologic disorder. He is currently doing well on appropriate therapy for this disorder.

\section{Introduction}

We report a diagnostic dilemma involving a 16-year-old male who presented with thrombocytopenia and nonspecific symptoms, including malaise and fever. He was diagnosed with a viral illness, although the thrombocytopenia persisted and he was found to have adenopathy and splenomegaly. $\mathrm{He}$ was ultimately diagnosed with an unusual infection acquired from livestock exposure. Although he was treated with appropriate antibiotics, the thrombocytopenia and splenomegaly persisted. An immunologic evaluation was ultimately performed and he was diagnosed more than two years after presentation. He was placed on appropriate therapy and is currently doing well. The protean manifestations of this disorder often result in a delayed diagnosis by several years and are reviewed in detail here. This disorder is more common than you think.

\section{Case Presentation}

A 16-year-old male presented with fever, malaise, and decreased energy for 3 days. He was diagnosed with a viral illness, although symptoms persisted. He developed bruising and lost 50 pounds over the ensuing 3 months. Physical examination showed an exudative pharyngitis. A throat culture was unremarkable and blood counts showed the following: hemoglobin $16 \mathrm{~g} / \mathrm{dL}$, white blood cell (WBC) count $3,400 / \mathrm{mm}^{3}$, and platelet count $80,000 / \mathrm{mm}^{3}$; a differential was not obtained.

Four months later, he was evaluated by an oncologist who noted axillary and inguinal adenopathy. The abdomen was obese and hepatosplenomegaly was not appreciated. Blood counts showed the following: hemoglobin $15.5 \mathrm{~g} / \mathrm{dL}$, platelet count $66,000 / \mathrm{mm}^{3}$ and WBC $2,900 / \mathrm{mm}^{3}$ with $54 \%$ neutrophils, $32 \%$ lymphocytes, $9 \%$ monocytes, and $5 \%$ eosinophils. There were atypical, reactive-appearing lymphocytes on the peripheral blood smear. Computed tomography (CT) of the chest, pelvis, and abdomen showed splenomegaly $(19 \mathrm{~cm})$ and diffuse abdominal lymphadenopathy. A biopsy of the left axillary node revealed reactive hyperplasia. Bone marrow aspirate and biopsy showed mild hypocellularity with normal trilineage hematopoiesis and no evidence for 
TABLE 1: Clinical manifestations of Q fever [1-6].

\begin{tabular}{|c|c|c|c|c|c|c|c|}
\hline Symptoms & $\begin{array}{l}\text { Karagiannis } \\
\text { et al., } 2009 \text { [1] } \\
n=73\end{array}$ & $\begin{array}{c}\text { Sampere } \\
\text { et al., } 2003 \\
{[2]} \\
n=66\end{array}$ & $\begin{array}{l}\text { Raoult et al., } \\
2000[3] \\
n=1383\end{array}$ & $\begin{array}{c}\text { Domingo et al., } \\
\begin{array}{c}1999 \text { [4] } \\
n=63\end{array}\end{array}$ & $\begin{array}{l}\text { Tselentis et al., } \\
\begin{array}{c}1995 \text { [5] } \\
n=98\end{array}\end{array}$ & $\begin{array}{c}\text { Tissot Dupont } \\
\text { et al., } 1992[6] \\
n=323\end{array}$ & $\begin{array}{c}\text { Average } \\
(n=2,000)\end{array}$ \\
\hline Fever & $25 \%$ & $84 \%$ & $91 \%$ & $100 \%$ & $92 \%$ & $82 \%$ & $87 \%$ \\
\hline Hepatitis & & $33 \%$ & $62 \%$ & $48 \%$ & $52 \%$ & & $60 \%$ \\
\hline Malaise & $39 \%$ & $33 \%$ & $62 \%$ & $48 \%$ & $52 \%$ & $53 \%$ & $58 \%$ \\
\hline Headache & $41 \%$ & $42 \%$ & $51 \%$ & $56 \%$ & & & $50 \%$ \\
\hline Chills & & $29 \%$ & & $59 \%$ & & & $44 \%$ \\
\hline Pulmonary involvement & $22 \%$ & $56 \%$ & $34 \%$ & $41 \%$ & $89 \%$ & $38 \%$ & $38 \%$ \\
\hline Myalgia/arthralgia & $9 \%$ & $41 \%$ & $37 \%$ & $46 \%$ & & & $36 \%$ \\
\hline Thrombocytopenia & & & $35 \%$ & & & & $35 \%$ \\
\hline Cough & $37 \%$ & $27 \%$ & & $35 \%$ & & & $33 \%$ \\
\hline Hepatomegaly & & $24 \%$ & & $54 \%$ & $22 \%$ & & $31 \%$ \\
\hline GI symptoms & & $27 \%$ & & $19 \%$ & $16 \%$ & & $18 \%$ \\
\hline Splenomegaly & & & & $22 \%$ & $11 \%$ & & $16 \%$ \\
\hline Weight loss & $11 \%$ & & & & & & $11 \%$ \\
\hline Rash & & & $11 \%$ & $2 \%$ & $2 \%$ & $21 \%$ & $12 \%$ \\
\hline Lymphadenopathy & & & & & $7 \%$ & & $7 \%$ \\
\hline Palpitations & & & $4 \%$ & & & & $4 \%$ \\
\hline Neurological symptoms & & & $1 \%$ & & $12 \%$ & $9 \%$ & $3 \%$ \\
\hline Jaundice & $2 \%$ & & & & & & $2 \%$ \\
\hline Myocarditis & & & $1 \%$ & & & & $1 \%$ \\
\hline Pericarditis & & & $1 \%$ & & & & $1 \%$ \\
\hline
\end{tabular}

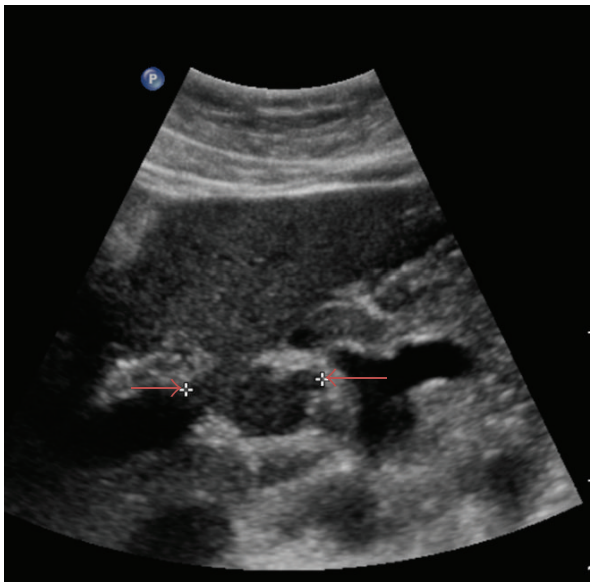

(a)

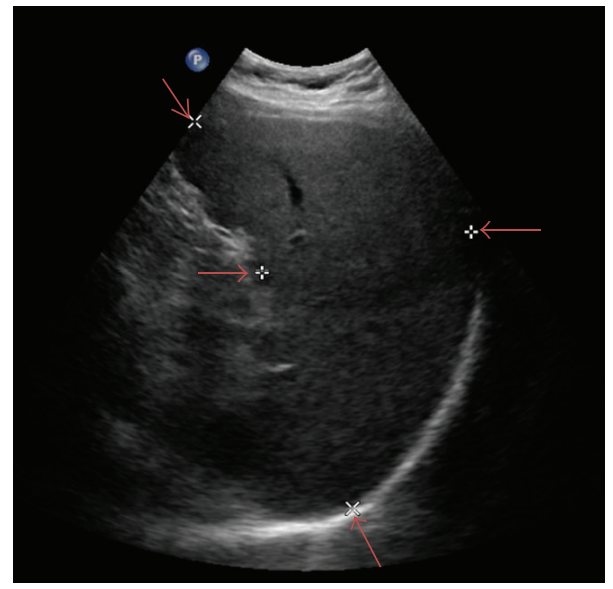

(b)

FIGURE 1: Abdominal ultrasound demonstrating lymphadenopathy and splenomegaly. (a) The lymph node diameter $(3.1 \mathrm{~cm})$ is demarcated by the arrows. (b) The spleen dimensions $(18.3 \mathrm{~cm} \times 9.3 \mathrm{~cm})$ are demarcated by the arrows.

malignancy. Flow cytometry of the lymph node and bone marrow showed no abnormalities.

The malaise persisted and the patient was evaluated by an infectious disease specialist 8 months after presentation. Physical examination was unremarkable; the adenopathy had resolved. Thrombocytopenia and leukopenia persisted (platelet count $73,000 / \mathrm{mm}^{3}$; WBC count $3,200 / \mathrm{mm}^{3}$ ).
Serology studies for CMV, EBV, HIV, and Bartonella were all negative. Because he worked on a farm with exposure to livestock, titers for brucellosis were sent and were negative. However, titers for Coxiella burnetii were consistent with an acute Q fever infection (phase I IgG Ab $<1: 16$, phase II IgG $1: 256)$. He was started on doxycycline (100 mg twice daily). A transthoracic echocardiogram showed possible vegetation, 
TABLE 2: Clinical manifestations of CVID [8-13].

\begin{tabular}{|c|c|c|c|c|c|c|c|}
\hline Symptoms & $\begin{array}{c}\text { Chapel et al., } \\
2008[10] \\
n=334\end{array}$ & $\begin{array}{c}\text { Oksenhendler } \\
\text { et al., } 2008 \text { [11] } \\
\quad n=252\end{array}$ & $\begin{array}{l}\text { Quinti et al., } \\
2007 \text { [12] } \\
n=224\end{array}$ & $\begin{array}{c}\text { Cunningham- } \\
\text { Rundles and } \\
\text { Bodian, } 1999 \text { [9] } \\
n=248\end{array}$ & $\begin{array}{c}\text { Hermaszewski } \\
\text { and Webster, } \\
1993[8] \\
n=240\end{array}$ & $\begin{array}{c}\text { Cunningham- } \\
\text { Rundles, } 1989 \\
{[13]} \\
n=103\end{array}$ & Average \\
\hline $\begin{array}{l}\text { Sinusitis, otitis media, } \\
\text { bronchitis, and } \\
\text { mastoiditis }\end{array}$ & & $69 \%$ & $86 \%$ & $98 \%$ & $36 \%$ & $100 \%$ & $75 \%$ \\
\hline Pneumonia & & $58 \%$ & $49 \%$ & $79 \%$ & $63 \%$ & $87 \%$ & $69 \%$ \\
\hline Bronchiectasis & $25 \%$ & $37 \%$ & & & $18 \%$ & & $27 \%$ \\
\hline Splenomegaly & $30 \%$ & $38 \%$ & & & $13 \%$ & & $27 \%$ \\
\hline Liver disease & & $17 \%$ & & & & & $17 \%$ \\
\hline Diarrhea & & $23 \%$ & $23 \%$ & $6 \%$ & $12 \%$ & & $16 \%$ \\
\hline Lymphadenopathy & $15 \%$ & & & & $5 \%$ & & $11 \%$ \\
\hline Urogenital infection & & & $7 \%$ & & $7 \%$ & & $7 \%$ \\
\hline Granulomatous disease & $8 \%$ & $14 \%$ & $3 \%$ & $8 \%$ & $1 \%$ & & $7 \%$ \\
\hline Thrombocytopenia & $7 \%$ & & $6 \%$ & $6 \%$ & $3 \%$ & $6 \%$ & $7 \%$ \\
\hline $\begin{array}{l}\text { Non-Hodgkin’s } \\
\text { lymphoma }\end{array}$ & $3 \%$ & & $2 \%$ & $8 \%$ & & $8 \%$ & $5 \%$ \\
\hline Herpes/varicella & & & & $4 \%$ & $7 \%$ & $2 \%$ & $5 \%$ \\
\hline Hepatomegaly & $9 \%$ & & & & $1 \%$ & & $5 \%$ \\
\hline Hemolytic anemia & $4 \%$ & & $3 \%$ & $5 \%$ & $3 \%$ & $5 \%$ & $4 \%$ \\
\hline Pernicious anemia & $9 \%$ & & & $1 \%$ & $2 \%$ & $1 \%$ & $4 \%$ \\
\hline Hepatitis & $2 \%$ & & & $7 \%$ & $1 \%$ & $12 \%$ & $4 \%$ \\
\hline Meningitis/encephalitis & & $8 \%$ & $1 \%$ & $1 \%$ & $7 \%$ & $4 \%$ & $4 \%$ \\
\hline Sepsis & & $13 \%$ & $1 \%$ & $1 \%$ & $2 \%$ & & $4 \%$ \\
\hline Malaise & & & & & $3 \%$ & & $3 \%$ \\
\hline Crohn's disease & $2 \%$ & & & $4 \%$ & & $1 \%$ & $3 \%$ \\
\hline Vitiligo & $5 \%$ & & $2 \%$ & & $2 \%$ & & $3 \%$ \\
\hline Atopic dermatitis & & & & & $2 \%$ & & $2 \%$ \\
\hline Osteomyelitis & & & & $1 \%$ & $3 \%$ & $1 \%$ & $2 \%$ \\
\hline $\begin{array}{l}\text { Autoimmune } \\
\text { neutropenia }\end{array}$ & $1 \%$ & & $3 \%$ & $1 \%$ & & & $2 \%$ \\
\hline Stomach cancer & & & $2 \%$ & $1 \%$ & & $2 \%$ & $2 \%$ \\
\hline Septic arthritis & & & $2 \%$ & $1 \%$ & $4 \%$ & $1 \%$ & $2 \%$ \\
\hline Psoriasis & $2 \%$ & & & & $1 \%$ & & $1 \%$ \\
\hline Oral candidiasis & & & $2 \%$ & $1 \%$ & $1 \%$ & & $1 \%$ \\
\hline Parotitis & & & & $1 \%$ & & $1 \%$ & $1 \%$ \\
\hline
\end{tabular}

although a transesophageal echocardiogram was normal. Thrombocytopenia and leukopenia persisted and repeat imaging studies 6 and 12 months after presentation showed persistent intra-abdominal adenopathy and splenomegaly. He was therefore treated with doxycycline for 2 years after which there was no detectable Coxiella DNA by polymerase chain reaction. Given the persistent cytopenias, adenopathy, and splenomegaly for $>2$ years, the patient was referred to our hematology clinic. Past medical history was notable for occasional atopic dermatitis and tonsillectomy at age 3 for recurrent pharyngitis. Family history was notable for a paternal uncle who died from metastatic colon cancer. There was no family history of other malignancies or unusual infections.
The patient appeared well and was afebrile with no appreciable adenopathy, organomegaly, or cutaneous bleeding. Blood counts showed the following: hemoglobin $15.4 \mathrm{~g} / \mathrm{dL}$, platelet count $100,000 / \mathrm{mm}^{3}$, and WBC count $4,077 / \mathrm{mm}^{3}$ with $25 \%$ lymphocytes, $8 \%$ monocytes, $63 \%$ neutrophils, and $4 \%$ eosinophils. The peripheral blood smear showed occasional, atypical, reactive-appearing lymphocytes. Peripheral blood flow cytometry showed no clonal abnormalities. Abdominal ultrasound showed persistent splenomegaly and adenopathy (Figure 1).

Although thrombocytopenia and splenomegaly can be associated with Q fever (Table 1) [1-6], the persistent cytopenias, adenopathy, and splenomegaly are distinctly unusual after 2 years of appropriate antibiotic therapy. Lymph node 
TABLE 3: Genes implicated in CVID $[7,10]$.

\begin{tabular}{|c|c|c|c|c|c|}
\hline Gene symbol & Protein encoded & Protein function & $\begin{array}{c}\text { Chromosomal } \\
\text { location }\end{array}$ & $\begin{array}{l}\text { Estimated } \\
\% \text { CVID } \\
\text { patients }\end{array}$ & Reference \\
\hline CD19 & CD19 & $\begin{array}{l}\text { Protein component of the B-cell } \\
\text { receptor complex }\end{array}$ & $16 p$ & $<1 \%$ & $\begin{array}{l}\text { Chapel et al., } \\
2008[10]\end{array}$ \\
\hline ICOS & $\begin{array}{l}\text { Inducible } \\
\text { costimulator of } \\
\text { activated T-cells }\end{array}$ & $\begin{array}{l}\text { Expressed on activated T-cells; } \\
\text { facilitates cooperation between B } \\
\text { and T-cells }\end{array}$ & $2 q$ & $2 \%$ & $\begin{array}{c}\text { Cunningham- } \\
\text { Rundles, } 2010 \\
\text { [7] }\end{array}$ \\
\hline TNFRSF13B & $\begin{array}{l}\text { Transmembrane } \\
\text { activator and } \\
\text { calcium-modulator } \\
\text { and cyclophilin ligand } \\
\text { (TACI) }\end{array}$ & $\begin{array}{l}\text { Induces activation of } \\
\text { transcription factors (NFAT, AP1, } \\
\text { and NF-kappaB) and plays a } \\
\text { crucial role in humoral immunity } \\
\text { by interacting with a TNF ligand }\end{array}$ & $17 \mathrm{p}$ & $8 \%$ & $\begin{array}{c}\text { Cunningham- } \\
\text { Rundles, } 2010 \\
\text { [7] }\end{array}$ \\
\hline TNFRSF13C & $\begin{array}{l}\text { BAFF-R, B-cell } \\
\text { activating factor of } \\
\text { the TNF family } \\
\text { receptor }\end{array}$ & $\begin{array}{l}\text { B-cell receptor specific for } \\
\text { B-cell-activating factor (BAFF) } \\
\text { which enhances B-cell survival }\end{array}$ & $22 q$ & Unknown & $\begin{array}{c}\text { Chapel et al., } \\
2008 \text { [10] }\end{array}$ \\
\hline Msh5 & MSH5 & $\begin{array}{l}\text { Involved in DNA mismatch } \\
\text { repair or meiotic recombination } \\
\text { processes }\end{array}$ & $6 \mathrm{p}$ & $12 \%$ & $\begin{array}{c}\text { Chapel et al., } \\
2008 \text { [10] }\end{array}$ \\
\hline MS4A1 (CD20) & MS4A1 & $\begin{array}{l}\text { Encodes a B-lymphocyte surface } \\
\text { molecule involved in } \\
\text { development and differentiation } \\
\text { of B-cells into plasma cells }\end{array}$ & $11 q 12-q 13$ & $<1 \%$ & $\begin{array}{c}\text { Cunningham- } \\
\text { Rundles, } 2010 \\
\text { [7] }\end{array}$ \\
\hline CD81 & CD81 (TAPA1) & $\begin{array}{l}\text { Mediates signal transduction } \\
\text { events involved in regulating cell } \\
\text { development, growth, and } \\
\text { motility }\end{array}$ & 11p15.5 & $<1 \%$ & $\begin{array}{l}\text { Cunningham- } \\
\text { Rundles, } 2010 \\
\text { [7] }\end{array}$ \\
\hline
\end{tabular}

and bone marrow biopsies showed no evidence for malignancy. Thrombocytopenia can also occur with antiplatelet antibodies and immune-mediated thrombocytopenia purpura (ITP), although this is not typically associated with splenomegaly or leukopenia. The constellation of splenomegaly, thrombocytopenia, and leukopenia can also be caused by other immunological disorders. Thus, the patient's immunologic function was evaluated further and total quantitative immunoglobulin levels showed a profound deficiency (IgG $184 \mathrm{mg} / \mathrm{dL}$ (normal 751-1560), IgA $<7 \mathrm{mg} / \mathrm{dL}$ (normal 82-453), and IgM of $7 \mathrm{mg} / \mathrm{dL}$ (normal 46-304)). Following immunization to pneumococcus and tetanus, he had no detectable IgG antibodies to these vaccines. The inability to produce sufficient antibodies together with splenomegaly, thrombocytopenia, leukopenia, and hypogammaglobulinemia is consistent with common variable immune deficiency (CVID).

Our patient remains well on standard CVID therapy with weekly infusions of subcutaneous gamma globulin. His platelet count has remained stable $\left(>100,000 / \mathrm{mm}^{3}\right)$ and he has not had any significant infections.

\section{Discussion}

CVID is the most common primary immunodeficiency disorder [7-13]. CVID is characterized by the impaired secretion of antibodies (hypogammaglobulinemia; Table 2) and affects $1 / 10,000$ to $1 / 100,000$ individuals. The onset of symptoms typically occurs after puberty, but before 30 years [7-11]. Defective B-cell differentiation with inadequate secretion of immunoglobulins is the hallmark. Most patients experience a variety of complications, including respiratory tract infections, gastrointestinal symptoms, autoimmune disorders, malignancies, and viral infections. CVID is a diagnosis of exclusion with the following criteria: (1) age $\geq 4$ years, (2) profound hypogammaglobulinemia, (3) failure to generate antibodies after exposure to two or more protein antigens, and (4) exclusion of other causes of hypogammaglobulinemia. The average period between onset of symptoms and diagnosis is six to eight years [7]. Despite the deficiency in antibody production, autoimmune diseases (immune-mediated thrombocytopenia, hemolytic anemia) are relatively common, and cytopenias occur in $\sim 12 \%$ of patients [7-13]. Nonmalignant lymphoproliferative diseases are also common and manifested by lymphadenopathy and splenomegaly. Lymphoid hyperplasia can be difficult to distinguish from lymphoma, although most cases are benign $[7,8,12]$. Nonetheless, patients have an increased risk of lymphoid malignancies, particularly lymphoma $(\sim 5 \%)[8,10$, $11,13]$. Epidemiologic studies suggest an autosomal recessive mode of inheritance, although there are rare families that appear to have an autosomal dominant inheritance pattern. About $10-15 \%$ of CVID patients have disease-specific alleles and $90 \%$ of these appear to arise as de novo germline mutations $[7,9,10]$. Disease-specific alleles have been identified 
in CD19, ICOS, TNFRSF13B, TNFRSF13C, CD20, CD81, and Msh5 genes (Table 3) $[7,10]$.

Like CVID, Q fever can be a challenging diagnosis because of nonspecific symptoms (Table 1) [1-6]. Q fever is a zoonotic disease caused by Coxiella burnetii and transmitted to humans following contact with livestock (goats, cattle, and sheep) and inhalation of aerosolized particles. Q fever has a widespread geographic distribution worldwide with sporadic outbreaks. Since Q fever became a reportable disease in the USA in 1999, its incidence has been increasing [1, 2 , 4]. Diagnosis relies on serologic findings, characterized by antibodies to phase I and phase II antigens that result from lipopolysaccharide modifications. The most common manifestations include fever, headaches, myalgias, malaise, and hepatitis [1-6]. Thrombocytopenia occurs in $~ 35 \%$ of the cases but is more commonly associated with endocarditis or pregnancy [3]. Treatment is typically doxycycline for two weeks. In chronic infections (lasting $>6$ months), $\operatorname{IgG}$ phase I antibodies predominate and are often $>1: 800$ [5]. Endocarditis is the most common complication of chronic infection [2]. An echocardiograph is recommended for all patients, and those with vegetations should be treated for $\geq 12$ months [2]. Serology studies are monitored at 3 and 6 months after the initial diagnosis to determine chronicity. Chronic Q fever is treated with doxycycline and hydroxychloroquine ( $\geq 18$ months) [5]. Alternatively, doxycycline and ofloxacin can be used, but this typically requires longer durations of treatment ( $\geq 3$ years) [5].

This case highlights the protean and often elusive manifestations of CVID, which led to a delayed diagnosis in our patient despite characteristic symptoms. The unusual infection (Coxiella burnetii) made the diagnosis challenging because chronic infections with $\mathrm{Q}$ fever can occur and mimic CVID. Nonetheless, the diagnosis of CVID should be considered in all patients presenting with cytopenias, splenomegaly, and atypical infections because therapy with gamma globulin is effective, as demonstrated by this interesting patient.

\section{Conflict of Interests}

The authors of the paper do not have a direct financial relationship with any commercial identities related to this case.

\section{References}

[1] I. Karagiannis, B. Schimmer, A. van Lier et al., "Investigation of a Q fever outbreak in a rural area of The Netherlands," Epidemiology and Infection, vol. 137, no. 9, pp. 1283-1294, 2009.

[2] M. Sampere, B. Font, J. Font, I. Sanfeliu, and F. Segura, "Q fever in adults: review of 66 clinical cases," European Journal of Clinical Microbiology and Infectious Diseases, vol. 22, no. 2, pp. 108-110, 2003.

[3] D. Raoult, H. Tissot-Dupont, C. Foucault et al., "Q fever 19851998: clinical and epidemiologic features of 1383 infections," Medicine, vol. 79, no. 2, pp. 109-123, 2000.

[4] P. Domingo, C. Muñoz, T. Franquet, M. Gurguí, F. Sancho, and G. Vazquez, "Acute Q fever in adult patients: report on 63 sporadic cases in an urban area," Clinical Infectious Diseases, vol. 29, no. 4, pp. 874-879, 1999.

[5] Y. Tselentis, A. Gikas, D. Kofteridis et al., "Q fever in the Greek Island of Crete: epidemiologic, clinical, and therapeutic data from 98 cases," Clinical Infectious Diseases, vol. 20, no. 5, pp. 1311-1316, 1995.

[6] H. Tissot Dupont, D. Raoult, P. Brouqui et al., "Epidemiologic features and clinical presentation of acute Q fever in hospitalized patients: 323 French cases," American Journal of Medicine, vol. 93, no. 4, pp. 427-434, 1992.

[7] C. Cunningham-Rundles, "How I treat common variable immune deficiency," Blood, vol. 116, no. 1, pp. 7-15, 2010.

[8] R. A. Hermaszewski and A. D. B. Webster, "Primary hypogammaglobulinaemia: a survey of clinical manifestations and complications," Quarterly Journal of Medicine, vol. 86, no. 1, pp. 3142, 1993.

[9] C. Cunningham-Rundles and C. Bodian, "Common variable immunodeficiency: clinical and immunological features of 248 patients," Clinical Immunology, vol. 92, no. 1, pp. 34-48, 1999.

[10] H. Chapel, M. Lucas, M. Lee et al., "Common variable immunodeficiency disorders: division into distinct clinical phenotypes," Blood, vol. 112, no. 2, pp. 277-286, 2008.

[11] E. Oksenhendler, L. Gérard, C. Fieschi et al., "Infections in 252 patients with common variable immunodeficiency," Clinical Infectious Diseasee, vol. 46, no. 10, pp. 1547-1554, 2008.

[12] I. Quinti, A. Soresina, G. Spadaro et al., "Long-term follow-up and outcome of a large cohort of patients with common variable immunodeficiency," Journal of Clinical Immunology, vol. 27, no. 3, pp. 308-316, 2007.

[13] C. Cunningham-Rundles, "Clinical and immunologic analyses of 103 patients with common variable immunodeficiency," Journal of Clinical Immunology, vol. 9, no. 1, pp. 22-33, 1989. 


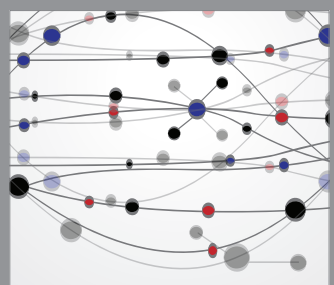

The Scientific World Journal
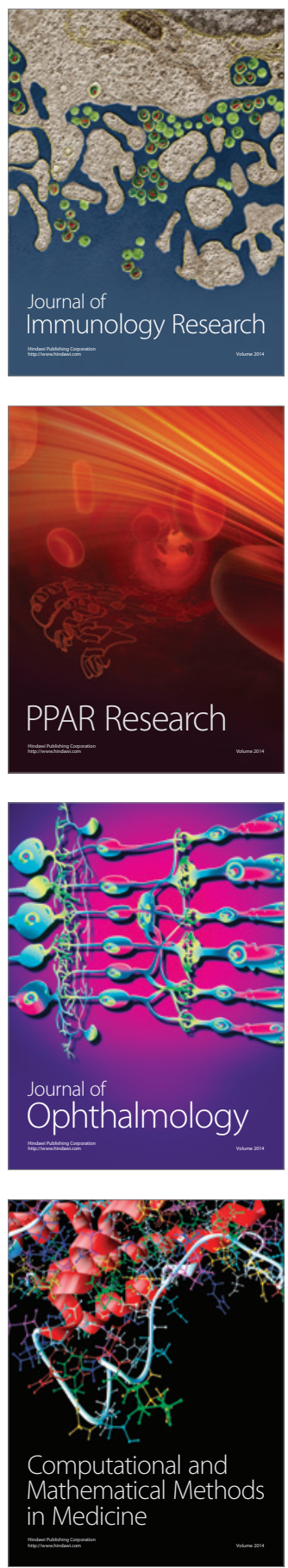

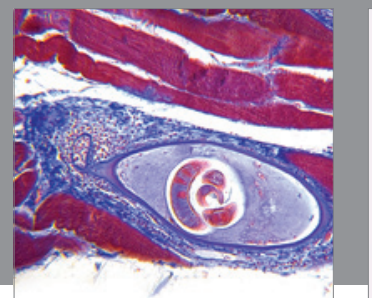

Gastroenterology

Research and Practice
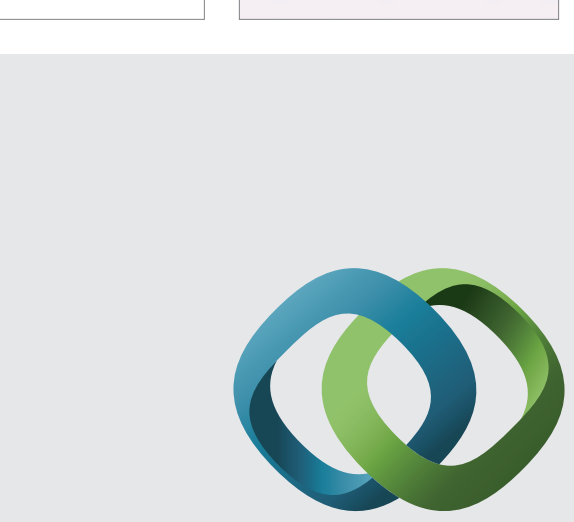

\section{Hindawi}

Submit your manuscripts at

http://www.hindawi.com
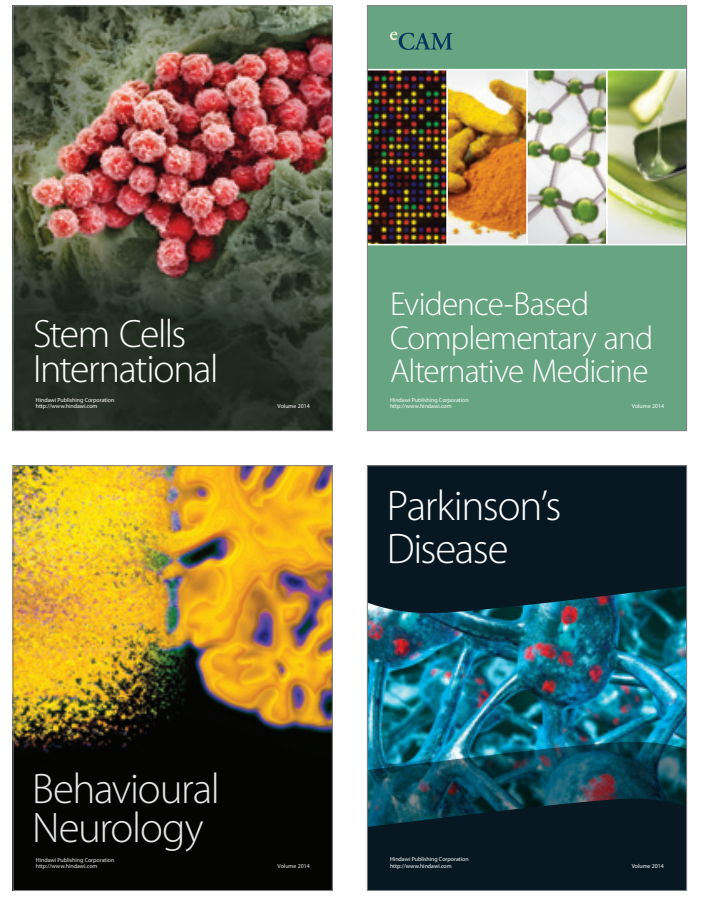
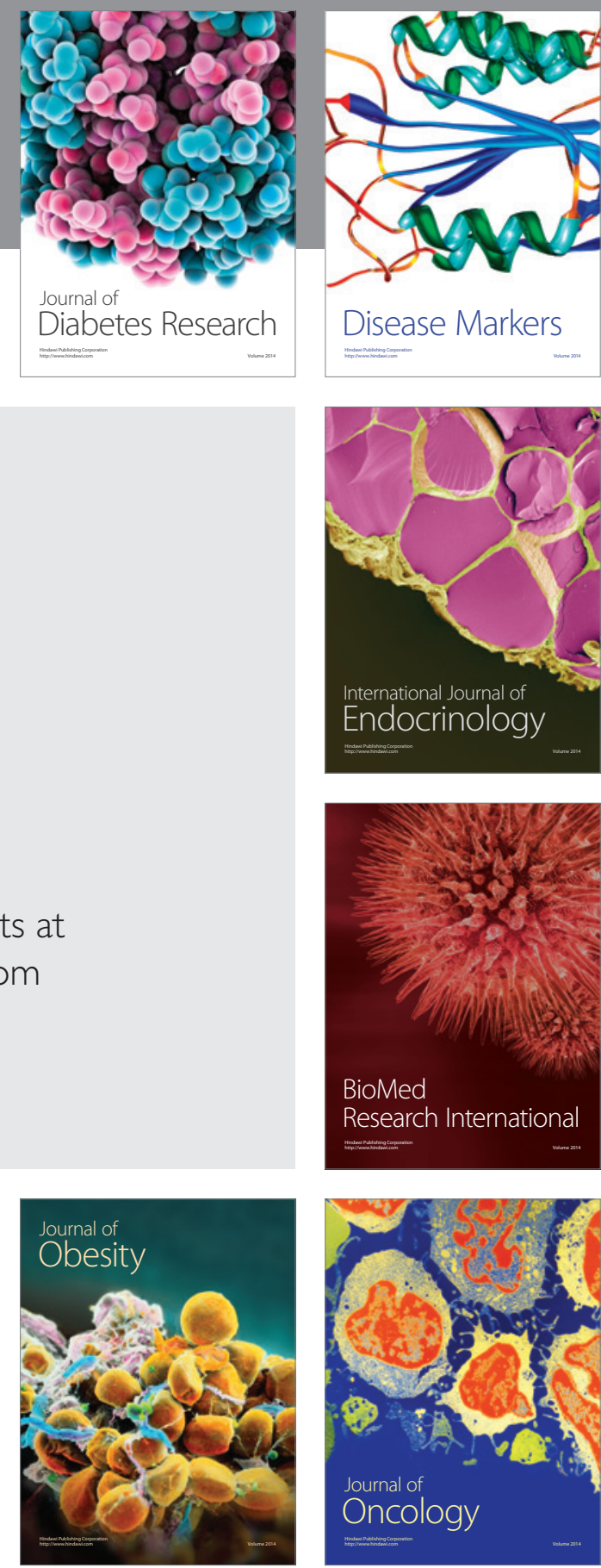

Disease Markers
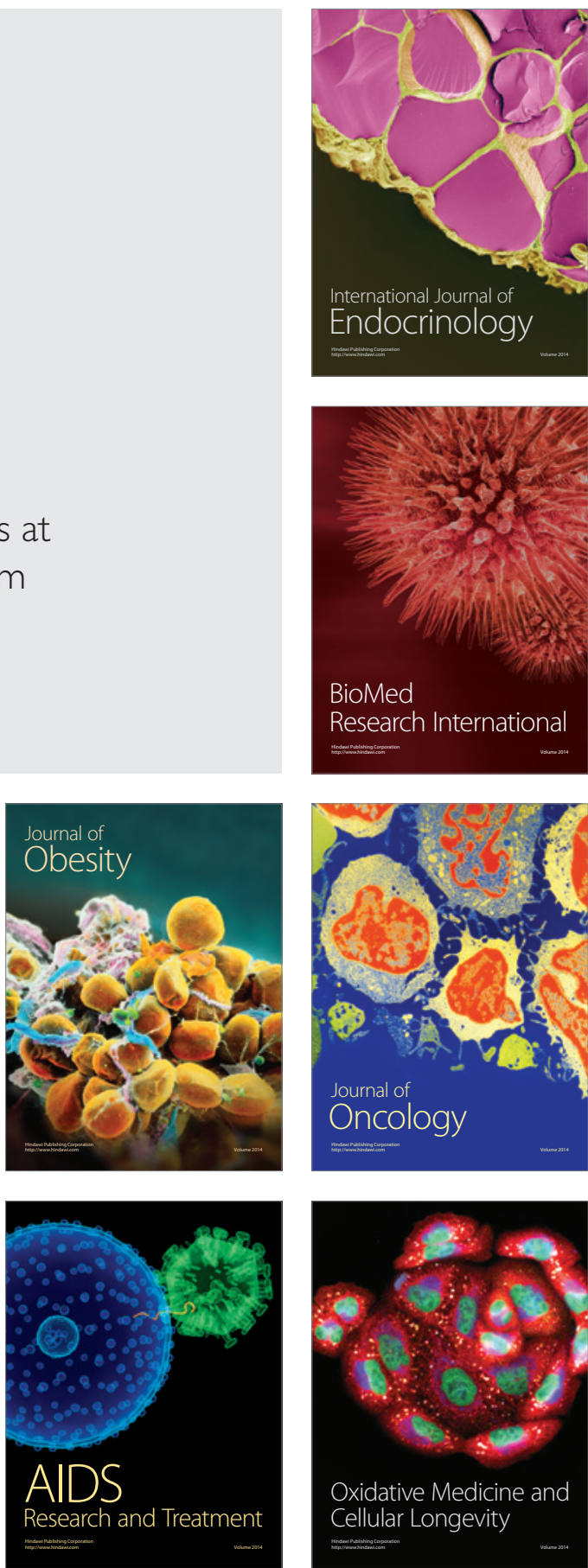